\title{
Conceptualizing State Strength: Moving Beyond Strong and Weak States*
}

\author{
Conceptualizando la fortaleza del Estado: \\ Más allá de los estados débiles o fuertes
}

\author{
AGUSTINA GIRAUDY \\ Harvard Academy for International and Area Studies, Harvard University and American University
}

\begin{abstract}
The strength of states has long been regarded by the specialized literature as an important factor to guarantee the viability of different political and economic phenomena such as democratic consolidation, the rule of law, adequate provision of basic public goods, and economic growth. Despite the importance of state strength, only few scholarly works have systematically explored the definition and the constitutive dimensions of this concept. This article seeks to (a) refine the conceptualization of state strength, (b) increase awareness about the effects of different rules of aggregation for achieving differentiation among empirical cases (i.e., countries), and (c) provide conceptual tools to help analysts move beyond the classical dichotomy of strong states versus weak states.
\end{abstract}

Key words: State strength, Conceptualization, Strong States Vs. Weak States, Hybrid States.

\section{RESUMEN}

La literatura especializada ha considerado a la capacidad estatal como un factor importante para garantizar la viabilidad de diferentes fenómenos políticos y económicos como, por ejemplo, la consolidación democrática, el estado de derecho, la adecuada provisión de bienes públicos y el crecimiento económico. A pesar de la importancia de la capacidad estatal, solo algunos pocos trabajos académicos han explorado sistemáticamente la definición así como las dimensiones constitutivas de este concepto. Este artículo busca (a) precisar la conceptualización de capacidad estatal, (b) echar luz sobre los efectos que tienen las reglas de agregación a efectos de alcanzar diferenciación entre casos empíricos (e.g., países) y (c) brindar herramientas conceptuales para superar la clásica dicotomía entre estados débiles y estados fuertes.

Palabras clave: Capacidad estatal, conceptualización, estados fuertes vs. estados débiles, estados híbridos.

* I thank all members of the Núcleo Milenio NS 100014 Project for the invitation to participate in the conference "Stateness in Latin America in the 21st Century: Conceptual Challenges", held in Santiago de Chile in March, 2012. I am also grateful to Andreas Feldmann, Vicky Murillo, one anonymous reviewer, as well as participants of the conference for their insightful comments. This article is part of the Millenium Nucleus for the Study of Stateness and Democracy in Latin America, Project NS100014, of the Ministry of Economy and Tourism of Chile. 
The strength of states has long been regarded as an important factor to guarantee, among other things, democratic consolidation (Linz and Stepan, 1996), the rule of law (O'Donnell, 1993), adequate provision of basic public goods (Rotberg, 2004), and economic growth (Coatsworth, 1998). Despite the importance of state strength, only few scholarly works have systematically explored its constitutive dimensions. Similarly, little discussion exists about how these dimensions should be aggregated in order to increase analytical and empirical differentiation among cases (i.e., countries). This absence of literature is striking given the fundamental importance of concept formation and rules of aggregation for bounding the range of real-world cases covered by a term, constructing theoretical propositions, assessing causal relationships, and cumulating knowledge (Sartori, 1970; Collier and Mahon, 1993; Munck, 2004; Goertz, 2006; Kurtz, 2009; Gerring, 2012).

To further complicate the issue, research on state strength has been, for the most part, approached from a 'dichotomous' perspective, in that states are viewed as either strong or weak. This is problematic because most states, with the exception of the European states, which are generally regarded as strong, are lumped together in one conceptual category. As a result, the label 'weak states' denotes a variety of empirical cases that, in practice and by relevant scholarly standards, differ widely from each other. The resulting conceptual stretching, in turn, seriously affects the proper theoretical and empirical understanding of most of the existing states in the developing world.

The goal of this article is three-fold. First, it seeks to refine the conceptualization of state strength. To do so, the essay draws on and further expands the insights into the conceptualization of state strength provided by Soifer and vom Hau (2008) and Soifer (2008). Second, the article aims to increase awareness about the importance of rules of aggregation for achieving differentiation among empirical cases. In particular, it seeks to highlight how the choice of specific rules of aggregation determines the range of empirical cases that are encompassed by the categories of "strong state" and "weak state". Finally, the article aims at helping analysts move beyond the classical dichotomy of strong states versus weak states by unpacking the category of weak states. To do so, the study draws on the diminished subtypes conceptual strategy to capture the diverse forms of weak states that have emerged in developing countries.

The article is organized as follows. The first section is an exercise to translate Soifer (2008) and Soifer and vom Hau's (2008) discussion on state strength into a two level conceptual scheme. The second section discusses the central premises and limitations of two strategies to achieve analytic differentiation, Gary Goertz's (2006) prototypical concept structures, the family resemblance approach and the necessary and sufficient concept structure. Section three outlines a third approach to achieving analytical and empirical differentiation, the so-called 'diminished subtypes' approach that, as argued below, has greater potential to help researchers move beyond the strong-weak state dichotomy. The article concludes by summarizing the main points of the essays and by discussing the analytic contributions that result from unpacking the category of weak states. 


\section{CONCEPTUALIZING STATE STRENGTH: THE BASIC AND PRIMARY LEVELS}

Soifer and vom Hau (2008) argue that most scholars who wrestle with state strength usually resort to assessing state capacity which is broadly a function of state bureaucracy, the state's relations with social actors, and its spatial and societal reach (2008:220). ${ }^{1}$ Drawing on an extensive literature review of renowned scholarly works on the state, Soifer and vom Hau (2008) argue that three different research programs have tapped into the core dimensions of state strength. The first research program studies the state's capacity (or lack thereof) to penetrate evenly throughout the territory it seeks to govern. ${ }^{2}$ A second research program addresses the capacity (or lack thereof) of the state to implement policy autonomously from social groups. ${ }^{3}$ Finally, a third strand of research tackling another aspect of state strength analyzes the professionalization and/or institutionalization (or lack thereof) of state bureaucracies to implement policies, extract resources, and deliver public goods. ${ }^{4}$

From Soifer's (2008) and Soifer and vom Hau's (2008) discussions it is possible to conclude that state strength is a concept made up of three core dimensions: state territorial reach, state autonomy from non-state actors, and bureaucratized/professionalized state institutions. Figure 1 displays in graphic terms this conceptualization.

Figure 1: A conceptualization of state strength

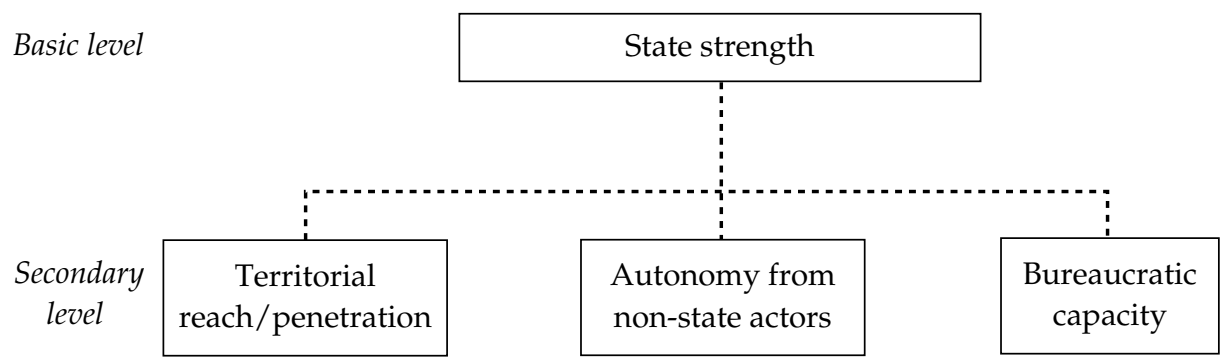

ontological

1 The authors argue that researchers studying these three dimensions of state strength or state capacity are actually exploring what Michael Mann has called state infrastructural power, that is, "the institutional capacity of a central state ... to penetrate its territories and logistically implement decisions" (Mann, 1986: 113). In Soifer and vom Hau's account, state strength is regarded as a synonym of state capacity and state infrastructural power.

2 Works in this tradition include, among others, Tilly (1990), Skocpol (1979), Herbst (2000), Centeno (2002), Boone (2003), Yashar (2005), Soifer (2006), Ziblatt (2008).

3 Illustrative works include, among others, Skocpol (1979), Bates (1981), and Evans (1995).

4 Some works in this tradition include, among others, Evans and Rauch (1999), Carpenter (2001), and Mazzuca (2007; 2010). 


\section{USING CONCEPT STRUCTURES TO DELIMIT THE RANGE OF EMPIRICAL CASES}

\section{Types of concept structures}

One of the main functions of concepts is to set clear boundaries to establish the empirical domain of cases covered by a term. As researchers of state strength we want to know what specific cases (i.e., countries) fall into the category of weak states and what others pertain to the category of strong states. Goertz (2006) contends that one (often neglected) way to increase a concept's ability to clearly delimit the empirical domain of cases is by determining a concept's structure type. Concepts, as he claims, generally belong to either one of two prototypical concept structures: the necessary and sufficient concept structure or the family resemblance concept structure. ${ }^{5}$

The first structure type views a concept's ontological dimensions as necessary and jointly sufficient. Accordingly, in order for a country to be conceived as having a strong state, the three core dimensions described above must be present. ${ }^{6}$ In this view, strong states exists where the central state (i) penetrates evenly throughout the territory it claims to govern, regulate, and control; (ii) exerts political power autonomously from non-state actors, and (iii) relies on a professionalized, institutionally capable, and resourceful bureaucracy to carry out public policies and enforce the rule of law.

Unlike the necessary and sufficient concept structure, the family resemblance structure "is a rule about sufficiency with no necessary condition requirements" (Goertz, 2006: 36). The label for this type of concept structure, as Collier and Mahon (1993) contend, "derives from the fact that we can recognize the members of a human genetic family by observing attributes that they share to varying degrees, as contrasted to nonfamily members who may share few of them. The commonalities are quite evident, even though there may be no trait that all family members, as family members, have in common" (Collier and Mahon, 1993: 847). In this view, there is no one dimension that a country must (necessarily) meet in order to be conceived as having a strong state. Thus, if a country has considerable territorial reach but lacks bureaucratic capacity, the country would still be regarded as a strong state.

\section{Rules of aggregation}

\section{a) The necessary and sufficient concept structure}

Goertz (2006) emphasizes that each of these concept structures follows a specific rule of aggregation through which a concept's core dimensions are combined, and which helps

\footnotetext{
As noted below, there are variants within each of these two general concept structures.

A variant of this type of structure within the necessary and sufficient concept structure is that two (or one) dimensions, instead of all, be present in order to classify a given country as a strong state. For the sake of simplicity, this variant is not analyzed in the paper for it would require debating whether territorial reach/ penetration, autonomy from non-state actors, and bureaucratic capacity exhaust (or not) the core dimensions of state strength. Following, the discussion presented in Section I, this article assumes that all three are constitutive and necessary dimensions of state strength. Future works, nonetheless, should address this issue.
} 
analysts achieve differentiation among empirical cases. The necessary and sufficient structure, Goertz (2006) contends, is mathematically modeled by the logical AND, whereby dimensions are aggregated through multiplication as shown in Figure 2.

This way of aggregating secondary-level dimensions sets clear boundaries to distinguish between cases that are strong and weak states. Where states (a) penetrate evenly throughout the territory they claim to govern, regulate, and control, (b) exert political power autonomously from non-state actors, and (c) rely on a professionalized, institutionally capable, and resourceful bureaucracy to carry out public policies, extract resources (i.e., taxes) from society, and deliver public goods, including the rule of law, cases ought to be conceived of as strong states. Contemporary South Korea, Taiwan, Germany, or Cuba before the Soviet collapse are unquestionably strong states because they meet the criteria listed above (Acemoglu, 2005; Slater, 2008; 2010; Herbst, 2000; Rotberg, 2004).

If, by contrast, any one or all three dimensions are absent (i.e., get a score of zero), the case cannot be regarded as a strong state. Since the necessary and sufficient concept structure has a dichotomous view of categories where membership is all or nothing, cases that fail to meet at least one of the core dimensions (e.g., territorial reach) are conceived of as weak states, regardless of whether they meet the remaining two constitutive dimensions (e.g., autonomy from non-state actors and bureaucratic capacity).

The necessary and sufficient concept structure thus helps researchers maximize empirical differentiation by setting clear boundaries to distinguish between strong and weak states. Nonetheless, this concept structure has low capacity to discriminate among very different weak states. As shown in Table 1, the label 'weak state' denotes cases (countries) that, in practice and by relevant scholarly standards, differ widely from each other. Moreover, the concept 'weak state' obscures what specific core dimension of state strength a given case fails to meet, and what others are present. As a result, 'weak state', as Table 1 shows, denotes something different in different cases. ${ }^{7}$

Figure 2: A necessary and sufficient conceptualization of state strength

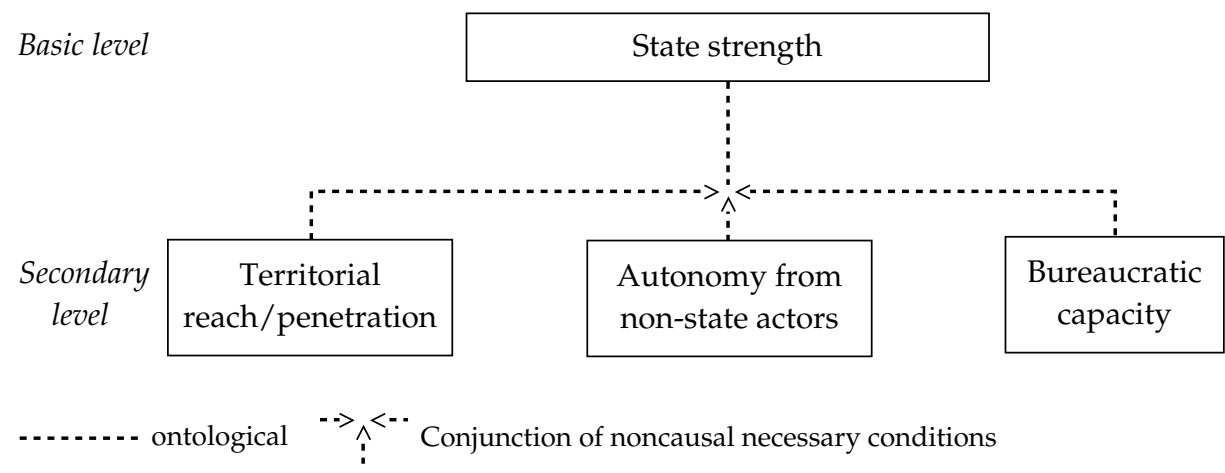

7 The literature on failed states has been particularly vulnerable to this problem of conceptual stretching. 
Table 1: Classification of cases using the necessary and sufficient concept structure

\begin{tabular}{ccccc}
\hline $\begin{array}{c}\text { Case } \\
\text { Labels }\end{array}$ & $\begin{array}{c}\text { Territorial } \\
\text { reach }\end{array}$ & $\begin{array}{c}\text { Bureaucratic } \\
\text { capacity }\end{array}$ & $\begin{array}{c}\text { Autonomy from } \\
\text { non-state actors }\end{array}$ & $\begin{array}{c}\text { Type } \\
\text { of state }\end{array}$ \\
\hline A & yes & yes & yes & Strong state \\
\hline B & yes & yes & no & Weak state \\
C & yes & no & yes & Weak state \\
D & yes & no & no & Weak state \\
E & no & yes & no & Weak state \\
F & no & yes & no & Weak state \\
G & no & no & yes & Weak state \\
H & no & no & no & Weak state \\
\hline
\end{tabular}

Take for instance the cases of Peru, Haiti, and Bolivia, which are generally regarded by the specialized literature as examples of weak states despite the fact that their 'weakness' results from the failure to meet different core dimensions. Whereas Peru is regarded as a weak state because it lacks territorial reach to penetrate the (Andean) countryside (Yashar, 2005), Bolivia is treated as a weak state due to its low levels of bureaucratic capacity and incapacity to penetrate the territory (Gray Molina, 2008). Haiti, by contrast, is considered a weak state because it cannot penetrate throughout the territory, does not have bureaucratic capacity to finance and distribute basic public goods, and fails to act autonomously from non-state actors (Rotberg, 2004; Baranyi, 2012). In sum, while extremely helpful to increase empirical differentiation between strong and weak states, the necessary and sufficient concept structure diminishes empirical differentiation within the category of weak states, as this type of state lumps together cases (i.e., countries) that differ widely among each other.

\section{b) The family resemblance concept structure}

As mentioned above, the family resemblance structure "is as a rule about sufficiency with no necessary condition requirements" (Goertz, 2006: 36). No single core dimension is necessary for a case to be considered a strong state; there are multiple ways in which a state can be strong. ${ }^{8}$ For this reason, secondary-level dimensions of a concept with a family resemblance concept structure are "connected" via the logical OR and aggregated through addition, as shown in Figure 3. This is the case because this type of concept structure allows for the absence of any given characteristic to be compensated for by the presence of another (Goertz, 2006: 39-44).

8 Note that this type of concept structure relaxes the assumption about the necessity of each of the three dimensions outlined in Section I. As noted in footnote 6, future works should address whether some of these dimensions are more necessary than others. 
Figure 3: A family resemblance conceptualization of state strength

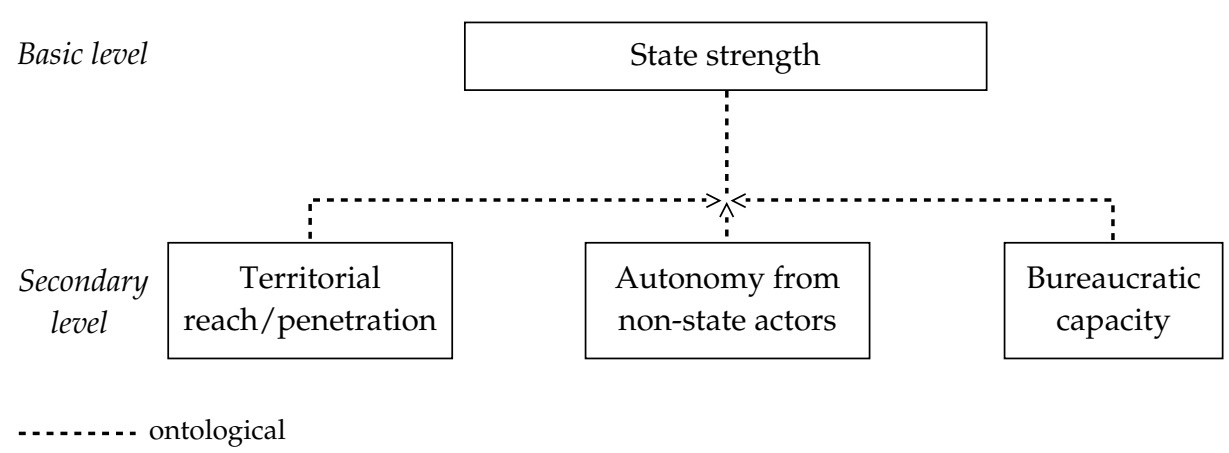

This way of aggregating secondary-level dimensions also sets clear boundaries to distinguish cases between strong and weak states. Cases that do not meet any of the three core dimensions are regarded as weak states. A country like Haiti, where state elites have only penetrated the capital and a half dozen other cities, and where beyond those urban centers "there are rarely any state security posts, courts, paved roads, public hospitals or even clinics, agricultural extension services or secondary schools" (Baranyi, 2012: 3), the state is undoubtedly weak. Moreover, lack of autonomy from international actors, who since 2004 have financed and administered public security and elections, has bred more state weakness (Baranyi, 2012).

If by contrast, any (or all) of the secondary-level core dimensions of state strength is (are) present, the case should be regarded as strong state. A case where the state's bureaucratic capacity is limited thus preventing it to deliver basic public goods or to tax its population, but which nonetheless has a state with pervasive territorial reach due to a favorable geographic context, is, according to the family resemblance concept structure, a case of a strong state. Strauss (2006), for instance, shows that Rwanda can still be regarded as a strong despite its weak bureaucratic capacity. He contends that the hilly topography of Rwanda and the heavily settled land increased the state's capacity for surveillance. This control over territory and population, Strauss argues, enabled the Rwandan state to implement policies of genocide -a policy regarded by the specialized literature as an indicator of the state's strong capacity to implement its will.

Like the necessary and sufficient concept structure, the family resemblance structure helps researchers maximize empirical differentiation by setting clear boundaries to distinguish between strong and weak states. Nonetheless, as occurs with the necessary and sufficient construction of weak states, the family resemblance concept structure has low capacity to discriminate among very different strong states. Moreover, the concept 'strong state' obscures what specific core dimension of state strength a given case fails to meet, and what others are present for a case to be consider as strong state. As a result, 'strong state', as Table 2 shows, denotes something different in different 
cases. For this reason, the family resemblance concept structure also ultimately fails to maximize empirical differentiation.

Table 2: Classification of cases using the family resemblance concept structure

\begin{tabular}{ccccc}
\hline $\begin{array}{c}\text { Case } \\
\text { Labels }\end{array}$ & $\begin{array}{c}\text { Territorial } \\
\text { reach }\end{array}$ & $\begin{array}{c}\text { Bureaucratic } \\
\text { capacity }\end{array}$ & $\begin{array}{c}\text { Autonomy from } \\
\text { non-state actors }\end{array}$ & $\begin{array}{c}\text { Type } \\
\text { of state }\end{array}$ \\
\hline H & no & no & no & Weak state \\
\hline A & yes & yes & yes & Strong state \\
B & yes & yes & no & Strong state \\
C & yes & no & yes & Strong state \\
D & yes & no & no & Strong state \\
E & no & yes & yes & Strong state \\
F & no & yes & no & Strong state \\
G & no & no & yes & Strong state \\
\hline
\end{tabular}

\section{MOVING BEYOND STRONG AND WEAK STATES}

Each of the two classical concept structures described in the previous section pose a fundamental trade-off for scholars studying state strength in developing countries, in particular in Latin America, where states are for the most part neither entirely strong nor necessarily weak. ${ }^{9}$ Whereas each one is useful to establish clearly demarcated borders between cases that pertain to the extreme categories (i.e., strong vs. weak states), they are less helpful for identifying real similarities and differences among cases where some (or all) core dimensions of state strength are missing or present. Perhaps more importantly, these concept structures fail to provide information about the specific dimensions that are present or absent among cases within each of these categories.

An alternative and promising strategy that can maintain the differentiation between strong and weak states, while also maximizing empirical and analytic differentiation among cases that fall in the 'grey zone' of state strength is the 'diminished subtypes' approach. Following Collier and Levitsky (1997), diminished subtypes should be regarded not as full instances of the root concept of state strength, i.e., instances where the three core dimensions are present. Instead, diminished subtypes should be understood as less than complete instances of strong states because they lack one or more components/core dimensions, and as more than complete instances of weak states, because they have one or more core dimension present. Diminished subtypes, as Collier and Levitsky (1997) note, help move beyond a dichotomous conceptualization of strong and weak states, as they help recognize the "hybrid" or "mixed" character of states, and, more importantly,

9 With the exceptions of Haiti, where the three core dimensions of state strength are missing, and Uruguay/ Costa Rica, where all dimension are present, most Latin American lack some attributes of state strength. 
as Figure 4 shows, they also contribute to creating and emphasizing differentiation by creating new analytic categories.

Figure 4: Diminished subtypes of state strength ${ }^{10}$

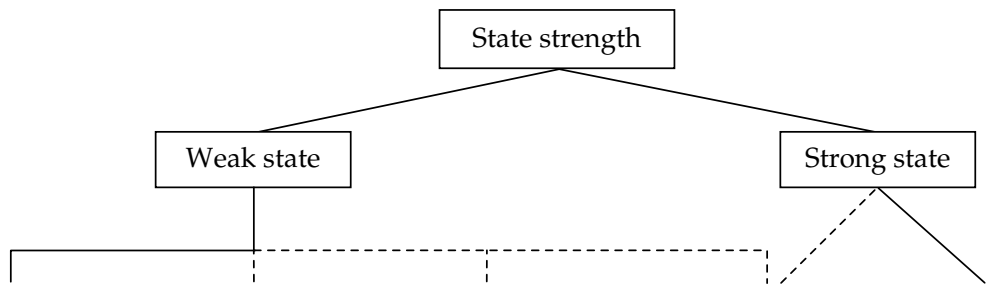

Missing dimensions: Missing dimension: Missing dimension: Missing dimensions: Missing dimensions: All 3

TR and BC

TR

Aut

None

Weak State

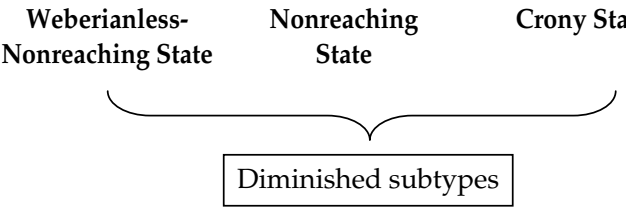

BC: Bureaucratic capacity TR: Territorial reach

Aut: Autonomy from non-state actors ------ Undefined membership

As seen in Figure 4, a distinctive feature of diminished subtypes is that "they generally identify the specific core dimension of [state strength] that is missing, thereby establishing the diminished character of the subtype at the same time that they identify other attributes of [state strength] that are present. Because they specify attributes, they also increase differentiation, and the diminished subtype in fact refers to a different set of cases than does the root meaning of [state strength]" (Collier and Levitsky, 1997: 437-438).

The inclusion and exclusion of cases that occurs with a diminished subtype strategy is illustrated in Table 3. Like the classification based on the necessary and sufficient concept structure, cases representing strong states result only when all three core dimensions are present. Examples of weak states, like in the taxonomy based on the family resemblance concept structure, exist only when all dimensions are absent. Cases illustrative of different types of diminished subtypes, in turn, result when one or more than one but not all dimensions are missing. As seen in Figure 4 and Table 3, cases under this strategy are clearly distinguished from one another, not only empirically but also analytically -i.e.,

10 Adapted from Goertz (2006)'s characterization of electoral regimes' diminished subtypes. For the sake of clarity and due to space limitations, only some combinations of missing attributes were included in this scheme. Diminished subtypes' labels presented in Figure 4 then, do not exhaust the universe of all possible combinations of missing attributes. 
each of them pertains to a specific subtype of state: "crony state", "non-reaching state", "Weberianless-non-reaching state". ${ }^{11}$

Table 3: Classification of cases using diminished subtypes ${ }^{12}$

\begin{tabular}{clcccl}
\hline $\begin{array}{c}\text { Case } \\
\text { Labels }\end{array}$ & $\begin{array}{c}\text { Missing } \\
\text { dimensions }\end{array}$ & $\begin{array}{c}\text { Territorial } \\
\text { reach }\end{array}$ & $\begin{array}{c}\text { Bureaucratic } \\
\text { capacity }\end{array}$ & $\begin{array}{c}\text { Autonomy from } \\
\text { non-state actors }\end{array}$ & $\begin{array}{c}\text { Type } \\
\text { of state }\end{array}$ \\
\hline A & None & yes & yes & yes & Strong state \\
H & All thee & no & no & no & Weak state \\
G & Two: TR, BC & no & no & yes & Non-reaching \\
E & One: TR & no & yes & yes & Non-reaching state \\
B & One: Aut & yes & yes & no & Crony state \\
\hline
\end{tabular}

Despite its contribution to maximizing analytic and empirical differentiation, three major problems arise when a strategy of diminished is employed. First, paraphrasing Collier and Levitsky (1997), diminished subtypes are useful for characterizing states that are neither strong nor weak, but they raise the issue of whether these states should in fact be treated as subtypes of strong states (as the dashed line in Figure 4, which denotes undefined membership, shows), rather than subtypes of weak states or some other concept (such as failed states). Second, diminished subtypes, as Munck (2006) notes, raise the central issue of the identification of thresholds that establish boundaries between categories and between cases. How many core dimensions need to be missing for a state to be classified in each particular intermediary category? Finally, while contributing to increase conceptual and empirical clarity, diminished subtypes, as Collier and Levitsky (1997) and Snyder (2006) underscore, can lead to a dangerous proliferation of concepts and terms which may result in additional conceptual confusion. Hence, diminished subtypes, or what is the same, the combination of two different concept structures, should be take cautiously.

\section{CONCLUDING REMARKS}

The goal of this short article has been to offer guidelines for scholars who are concerned with the conceptualization of state strength in developing countries. Furthermore, the article has sought to provide insights into different strategies to differentiate, both analytically and empirically, among cases that do not represent instances of either strong or weak states. Drawing on Soifer's (2008) and Soifer and vom Hau's (2008) rich

11 This is a very preliminary attempt to identify state subtypes. Labels such as "Weberianless-nonreaching state", "non-reaching state" or "crony state" are still awkward, and the subtypes displayed in Figure 4 do not necessarily exhaust the whole range of possible subtypes. Future works should come up with more felicitous labels to denote state subtypes.

12 As noted before, only some combinations of missing attributes are included in this table. Diminished subtypes' labels presented in Table 3 then, do not exhaust the universe of all possible combinations of missing attributes. 
discussion of studies of state strength, this article has developed a conceptualization and schematization of state strength made up of three core dimensions: state territorial reach, bureaucratic capacity, and autonomy from non-state actors.

The discussion about strategies to achieve empirical differentiation suggests that analysts of state strength in developing countries can benefit from adopting a strategy of diminished subtypes rather than Gary Goertz's (2006) classical approach of family resemblance and necessary and sufficient concept structures. Diminished subtypes, unlike the other two strategies, enables researchers to identify real similarities and differences among cases where some (or all) core dimensions of state strength are missing or present, thus maximizing empirical differentiation. As importantly, this strategy also increases analytic differentiation by enabling analysts to denote each subtype with a different conceptual label. Still, while maximizing analytical and empirical differentiation, this strategy, which creates new subtypes of states, might inevitably lead to conceptual fragmentation and proliferation of new conceptual labels. This in turn may increase the costs of delinking from earlier conceptual schemes with the associated risk of losing stock of existing knowledge. In order to avoid the loss and even decumulation of knowledge, analysts should ask whether the states that have emerged in the developing world are, or are not, sufficiently novel to warrant new categories and labels.

The strategy of diminished subtypes not only maximizes empirical differentiation but also contributes in important ways to refine our understanding of important political phenomena. As noted at the outset of this article, the strength of states has long been regarded as an important factor to guarantee, among other things, democratic consolidation (Linz and Stepan, 1996), the rule of law (O'Donnell, 1993), adequate provision of basic public goods (Rotberg, 2004), and economic growth (Coatsworth, 1998). Despite the importance of state strength, we know little about what of its constitutive dimensions, i.e., its territorial reach, its autonomy from non-state actors, and/or its bureaucratic capacity, shape each of these political and economic phenomena. It might be the case that each of state strength's dimensions impact critically but differently on democratic consolidation, the rule of law, the provision of public goods, economic, among others. The strategy of diminished subtypes, which allows researchers to be conscientious about what specific dimension of state strength prevails in each empirical case, and which at the same time allows scholar to isolate specific attributes of state strength, might help analysts refine our understanding of how state strength shape various political and economic processes.

\section{REFERENCES}

Acemoglu, Daron. 2005. "Politics and Economics in weak and strong states". Working Paper 11275 http:/ / www.nber.org/papers/w11275

Bates, Robert. 1981. Markets and states in tropical Africa. Berkeley: University of California Press.

Bates, Robert. 2008. When Things Fell Apart. State Failure in Late-Century Africa. Cambridge: Cambridge University Press.

Baranyi, Stephen. 2012. "Stateness and State-building in Haiti". Paper prepared for the Conference on Stateness in Latin America in the 21st Century, Santiago de Chile, March 29-30, 2012. 
Boone, Catherine. 2003. Political Topographies of the African State. Territorial Authority and Institutional Choice. Cambridge: Cambridge University Press.

Boudon, Lawrence. 1996. "Guerrillas and the State: The Role of the State in the Colombian Peace Process". Journal of Latin American Studies 28: 279-297.

Carpenter, Daniel. 2001. The forging of bureaucratic autonomy: reputations, networks, and policy innovation in executive agencies, 1862-1928. Princeton: Princeton University Press.

Centeno, Miguel Ángel. 2002a. Blood and Debt: War and the Nation-State in Latin America. University Park, PA: Pennsylvania State University Press.

Coatsworth, John H. 1998. "Economic and institutional trajectories in nineteenth century Latin America". In Coatsworth J. and Alan M. Taylor (eds.). Latin America and the world economy since 1800. Cambridge, Mass.: Harvard University/David Rockefeller Center for Latin American Studies.

Collier, David and Steven Levitsky. 1997. "Democracy with Adjectives: Conceptual Innovation in Comparative Analysis". World Politics 49: 430-451.

Collier, David and J. Mahon. 1993. "Conceptual "stretching" revisted: Adapting categories in comparative analysis". American Political Science Review 87: 845-855.

Di John, Jonathan. 2010. "The Concept, Causes and Consequences of Failed States: A Critical Review of the Literature and Agenda for Research with Specific Reference to Sub-Saharan Africa". European Journal of Development Research 221: 10-30.

Evans Peter. 1995. Embedded autonomy: states and industrial transformation. Princeton: Princeton University Press.

Evans Peter and James Rauch. "Bureaucracy and growth: a cross-national analysis of the effects of "Weberian" state structures on economic growth". American Sociological Review 64 (5 [Oct.]):748-765.

Gerring, John. 2012. Social Science Methodology. A Critical Framework. Cambridge: Cambridge University Press. Goertz, Gary. 2006. Social Science Concepts. A User's Guide. Princeton and Oxford: Princeton University Press. Gray Molina 2008. "State-Society Relations in Bolvia: The Strength of Weakness". In Crabtree, John and Laurence Whitehead (eds.). Unresolved tensions: Bolivia past and present. Pittsburgh, Pa.: University of Pittsburgh Press.

Herbst, Jeffrey. 2000. States and power in Africa. Princeton: Princeton University Press.

Kurtz, Marcus. 2009. "Peasant: claryfing the meaning and refining explanation". In Concepts and Method in Social Science. The Tradition of Giovanni Sartori, ed. David Collier and John Gerring. London: Routledge.

Linz, Juan and Alfed Stepan. 1996. Problems of democratic transition and consolidation: Southern Europe, South America, and post-communist Europe. Baltimore: Johns Hopkins University Press.

Mann, Michael. 1986. The Sources of Social Power 1: A History of Power from the Beginning to A.D. 1760. Cambridge: Cambridge University Press.

Mazzuca, Sebastián. 2007. "Reconceptualizing Democratization: Access to Power Versus Exercise of Power". In Regimes and Democracy in Latin America: Theory and Methods, ed. G. Munck. Oxford: Oxford University Press.

Mazzuca, Sebastián. 2010. "Access to Power versus Exercise of Power Reconceptualizing Democratic Quality in Latin America". Studies in Comparative International Development 45: 334-357.

O'Donnell, Guillermo. 1993. "On the State, Democratization and Some Conceptual Conceptual Problems: A Latin American View with Glances at Some Postcommunist Countries". World Development 21: 1355-1369.

Reno, William. 1995. Corruption and State Politics in Sierra Leone. Cambridge, U.K.: Cambridge University Press.

Reno, William. 2003. "Sierra Leone: Warfare in a Post-State Society". In R. I. Rotberg (ed.). State Failure and State Weakness in a Time of Terror, 71-100. Cambridge, MA, and Washington, DC: The World Peace Foundation/Brookings Institution.

Rotberg, Robert I. 2003. State Failure and State Weakness in a Time of Terror. Cambridge, Mass.: Washington, D.C.: World Peace Foundation ; Brookings Institution Press.

Rotberg, Robert I. 2004. When States Fail: Causes and Consequences. Princeton, N.J.: Princeton University Press.

Sartori, Giovanni. 1970. "Concept Misformation in Comparative Politics". The American Political Science Review 64 (4):1033-1053. 
Skocpol Theda. 1992. Protecting soldiers and mothers: the political origins of social policy in the United States. Cambridge, MA: Harvard University Press.

Slater, Dan. 2008. "Can Leviathan be Democratic? Competitive Elections, Robust Mass Politics, and State Infrastructural Power". Studies in Comparative International Development 43 (3 [Fall/Winter]): 252-272.

Slater, Dan. 2008. 2010. Ordering Power: Contentious Politics and Authoritarian Leviathans in Southeast Asia. Cambridge: Cambridge University Press.

Soifer, Hillel. 2008. "State Infrastructural Power: Approaches to Conceptualization and Measurement". Studies in Comparative International Development 3-4 (43): 231-251.

Soifer, Hillel. 2008. 2012. "Sketching an approach to conceptualization and measurement of 'stateness' for application to contemporary Latin America". Paper prepared for the Conference on Stateness in Latin America in the 21st Century, Santiago de Chile, March 29-30, 2012.

Soifer, Hillel and Matthias vom Hau. 2008. "Unpacking the Strength of the State: The Utility of State Infrastructure Power". Studies in Comparative International Development 3-4 (43): 219-30.

Strauss, Scott. 2006. The Order of Genocide. Ithaca, NY: Cornell University Press.

Tilly, Charles. 1990. Coercion, Capital and the European States, A.D. 990-1990. Cambridge MA \& Oxford UK. Blackwell.

Yashar, Deborah. 2005. Constructing citizenship in Latin America. Cambridge: Cambridge University Press.

Ziblatt, Daniel. 2008. “Why Some Cities Provide More Public Goods than Others: A Subnational Comparison of the Provision of Public Goods in German Cities in 1912". Studies in Comparative International Development 3-4 (43): 273-289.

\footnotetext{
Agustina Giraudy is Assistant Professor at American University. Ph.D. in Political Science (2009, University of North Carolina at Chapel Hill). Her research focuses on subnational democracy, subnational institutions, and federalism in Latin America. Her work has appeared in the Journal of Politics in Latin America, Latin American Research Review, Journal of Democracy (en Español), Studies in Comparative International Development, among others. She is currently completing a book manuscript on the continuity of subnational undemocratic regimes in democratic countries in the developing world. E-mail: agiraudy@wcfia.harvard.edu
} 
